\title{
Walking Gastrolinguistic Landscapes, with Metonymy as a Travel-guide
}

\author{
Mario Brdar \\ Faculty of Humanities and Social Sciences, University of Osijek, Osijek, Croatia
}

\begin{abstract}
A B S T R A C T
The present article is concerned with the role of metonymy in gastrolinguistic landscape, specifically with its role in creating a message for guests in the names of restaurants. Linguistic landscape is a relatively novel concept in contemporary linguistics, its methodology still in the flux, while its topics and approaches keep diversifying. The purpose of this article is to show that there is also a very important cognitive linguistic aspect to it. Specifically, the article points out the role of metonymy in creative examples of restaurant names that contain one or more elements from a language different from the rest of the restaurant name, focusing on the gastrolinguistic landscape of Central and Eastern Europe, primarily Croatia and Hungary. It is demonstrated that that in addition to some more general cultural models of language, speakers also have a multitude of specific folk models of particular languages, mostly based on stereotypes, which in turn are also metonymic. These activate a series of metonymic inferencing steps most of the time resulting in complex cumulative metonymies such that one is superimposed on the other, the target of one simultaneously functioning as the source for the next one, and so forth.
\end{abstract}

Key words: linguistic landscape; metonymy; stereotype; identity, prestige, cultural model

\section{Introduction}

Linguistic landscape is a relatively novel concept in contemporary linguistics. Sebba sees the study of it as "being somewhere at the junction of sociolinguistics, sociology, social psychology, geography and media studies"1. The purpose of this article is to show that there is also a very important cognitive linguistic aspect to it. Specifically, I would like to point out the role of metonymy in creative examples of restaurant names that contain one or more elements from a language different from the rest of the restaurant name, focusing on the gastrolinguistic landscape of Central and Eastern Europe, primarily Croatia and Hungary. I also show that in addition to some more general cultural models of language, speakers also have a multitude of specific folk models of particular languages, mostly based on stereotypes, which in turn are also metonymic. These activate a series of metonymic inferencing steps most of the time resulting in complex cumulative metonymies such that one is superimposed on the other, the target of one simultaneously functioning as the source for the next one, and so forth.

The article is organized as follows. Following a brief introduction of the topic of linguistic landscape, I turn to the phenomenon of metonymy and its role in the creation of cultural models and stereotypes. Special attention is given here to the cultural model of culture, the cultural/ folk model of language and folk models of particular languages, which give rise to certain stereotypes. In the central of the article I analyse a number of examples of restaurant names that employ various metonymies, often more than one, in creating their message to the public. The article concludes by summing up its main findings.

\section{Theoretical background}

\section{Linguistic landscape}

Landry and Bourhis define the phenomenon of linguistic landscape as "the visibility and salience of languages on public and commercial signs in a given territory or region". ${ }^{2}$ Linguistic landscape research is primarily concerned with visible language in public spaces, but transcends the written modality and also includes the interaction of language with pictures, colours and other meaningful pieces of information that may accompany text. The physical realization of language in public space

Received for publication October 15, 2021 
may include carriers such as traffic signs, official plates on government buildings, notice boards, advertising billboards, means of public and private transport, shop windows, posters, flags, banners, graffiti, stickers, menus, product packaging in shops, official bank notes and coins, and even lettered foot mats, T-shirts and tattoos, i.e. not only written text that is fixed and constantly on display "within a spatially definable frame"3, but also texts on dynamic carriers (which move, or can be switched on and off, covered and uncovered, and also modified).

As pointed out by Sebba, "[t]he linguistic landscapes paradigm has evolved rapidly and while it has a number of key names associated with it, it currently has no clear orthodoxy or theoretical core..."1. The concept of linguistic landscape originally applied to spaces in which more than one language was used, and it is still often understood in this way. This is also more or less implied by the above definition by Landry and Bourhis because of the plural form "languages". Van Mensel et al. ${ }^{4}$ use a more ambiguous form when they say that "the study of the linguistic landscape (LL) focuses on the representations of language(s) in public space." So, the studies by Heyd ${ }^{5}$ and Papen 6 deal with monolingual situations. However, the study of linguistic landscapes most of the time involves the presence of more than one language, in one form or another. The texts studied may be monolingual, possibly occuring together with texts in other languages, or they may be multilingual. The communities in which they occur may be predominantly monolingual or predominatnly multilingual.

Among research topics that stand out in the study of linguistic landscapes, we can identify two related issues that are of immediate relevance to the present article. One of them has to do with the construal of identity through the choice of the language(s) used, the other with the relative prestige associated with a given language in a particular usage event in a linguistic landscape. Backhaus noticed that some texts in a language that is different from the dominant language in the multilingual landscape are not really meant to (only) convey a genuine message but just to appeal to the readership because of the use of a more prestigious language. ${ }^{3}$ Texts may also visually, by the choice of the font, or the script, etc. conjure the impression of another language. ${ }^{7}$ Some scholars also looked into the patterns of the language choice according to the price of the commodity or service (e.g. new cars vs. used cars) or the sort of institutions they are used in (e.g. country club, hospital, ethnic grocery store, etc.). Carr compared the dominant languages of signs in in three urban areas in of different status in Southeast Los Angeles $^{8}$. She claims that signs in Spanish can boost individuals' sense of belonging and solidarity with their community. Al-Naimat found that global brands tend to use Roman scripts in Jordan to convey messages of prestige, success, and progress, among others, while the use of Arabic scripts is associated with issues that have to do with the local community and religious and social practices. ${ }^{9}$ Gradečak-Erdeljić and Zlomislić find that English is used as prestige booster in the linguistic landscape in Osijek, Croatia $^{10}$. Piller (2003) established that English indexes modernity and progress in German advertisements, while other languages tend to index ethnocultural stereotypes ${ }^{11}$. In a similar study Baumgardner also finds the use of English to index modernity in Mexican communities, along with its association with technology ${ }^{12}$. Kelly-Holmes (2005) documents how multiple languages and cultures are used to index an international identity as opposed to a traditional local or national identity ${ }^{13}$.

\section{Metonymy}

In order to fully understand the role metonymy plays in linguistic landscapes in general, and in restaurant names, we have to briefly introduce this basic cognitive process, i.e. define it and introduce its main types. Despite a whole volume devoted to the problem of defining meton$\mathrm{ymy}^{14}$, there is still no consensus on the issue. As Barcelona stresses, the fact that there is something most researchers would agree to call a "standard" cognitive-linguistic notion of conceptual metonymy that contains core elements of the cognitive view of metonymy, "it is by no means a completely uniform notion, as there is some disagreement among these authors over a number of issues"15.

Lakoff and Johnson describe metonymy as the use of "one entity to refer to another that is related to it"16. Kövecses and Radden refine this by explicitly shifting everything to the conceptual level when they say that it is "a cognitive process in which one conceptual entity, the vehicle, provides mental access to another conceptual entity, the target, within the same domain, or ICM [Idealized Cognitive Model]"17.

In view of the complex nature of conceptual metonymy, it can be seen, taking into account most of the relevant insights in the literature ${ }^{18-20}$, as a cognitive operation of conceptual elaboration based on the part-whole relationship that is triggered by the use of an expression (or metonymic vehicle) that is associated with a certain conceptual cluster (or metonymic source) within a conceptual domain so that the activation of the source conceptual cluster opens up a mental space that is dynamically expanded or reduced so as to come as close as possible to fitting the conceptual frame provided by the co(n)text of use, in the course of which the mental space thus opened and elaborated also comes very close in terms of its contents to another conceptual cluster (or metonymic target) within the same conceptual domain that may be or is typically associated with another expression. ${ }^{21-22}$

It is also assumed in cognitive linguistics that metonymy can involve a range of relationships, not only the WHOLE FOR PART relationship (as asserted in the traditional approach), but also the PART FOR WHOLE relationship (in which case we have a subtype traditionally called synecdoche). What is more, the PART FOR PART type of relationship has also been assumed, which comes in numerous subtypes, e.g. CAUSE FOR EFFECT, PRODUCER FOR PRODUCT, CON- 
TAINER FOR THE CONTAINED, etc., although the viability of this type is disputed by Ruiz Mendoza and his collaborators $^{23-26}$. They are better analysed as the outcome of the interaction between two or more successively used metonymies.

Within the cognitive linguistic framework, both these processes have been contrasted with respect to five central points of difference, although it has been repeatedly claimed that the borderline between the two is blurred $27-28,23$. The first of these four points of difference concerns the nature of the relationship involved. A standard ingredient of traditional definitions of metonymy is a statement on what makes it different from a non-figurative expression, viz. that metonymy is a stand-for type of relationship. In other words, a linguistic expression denoting a part of a larger whole is substituted by another expression denoting the whole, or the other way around. The relationship holding between the two is one of contiguity, association, or proximity ${ }^{29-30}$, whereas metaphor is based on similarity. This means that metonymies are expressions that are used instead of some other expressions because the latter are associated with or suggested by the former, as in "Buckingham Palace has washed its hands of Prince Harry and Meghan Markle after they told Americans to vote out Trump", where Buckingham Palace stands for the royal family.

Metaphors are in fact often considered to be shortened similes, i.e. two entities are brought into correlation as exhibiting some similarity, but there are no function words that would make this comparison explicit. In other words, something is described by mentioning another thing with which it is assumed to implicitly share some features. The two also differ in terms of the number of conceptual domains involved. The standard view is that a metonymic shift occurs within a single domain, while metaphoric mappings take place across two discrete domains. Conceptual metaphors typically employ a more concrete concept or domain as their source in order to structure a more abstract concept or domain as their target. They typically rest on a whole set of cross-domain mappings, while conceptual metonymies are said to involve only a single link ${ }^{31}$.

Thirdly, metaphor and metonymy are generally different with respect to the directionality of conceptual mappings involved. Metaphors typically employ a more concrete concept or domain as source in order to structure a more abstract concept or domain as target. In the majority of cases, elements from the physical world are mapped onto the social and mental world. Metaphorical mappings are thus normally unidirectional, and the source and target are not reversible ${ }^{32}$. Metonymic mappings can, in principle, proceed in either direction, from the more concrete part of the domain (subdomain) to the more abstract one and the other way round, but of course not simultaneously. According to Kövecses and Radden, "[i]n principle, either of the two conceptual entities related may stand for the other, i.e., unlike metaphor, metonymy is basically a reversible process" 17 .
Metaphor and metonymy are also said to have different functions. Lakoff and Johnson say that metaphor is "principally a way of conceiving of one thing in terms of another, and its primary function is understanding," while metonymy "has primarily a referential function, that is, it allows us to use one entity to stand for another"16. However, both of the above statements have to be relativized. While Lakoff and Johnson see metonymy as having primarily referential function they are aware of its additional functions and point out not only that metonymy is "naturally suited for focussing"16, but that it can just like metaphor have a role in construal. It makes it possible for us to see and understand things in alternative ways. In fact, a whole range of pragmatic effects of metonymy can be observed ${ }^{33}$. In this article we are going to see how it can help construe identity as well as produce some axiological effects in the sense of raising the prestige of certain establishments via activating certain cultural models of languages.

\section{Cultural models and stereotypes (of language(s))}

We do not need at this point concern ourselves with such big questions as "what is culture" in order to understand the notion of cultural models. We only need to take a more practical view on culture, i.e. see it in action, i.e. consider how it can be operationalized. We see cultural models as conceptualizations applied, i.e. tailored to measure for the purpose of providing a handle on a situation. They are localized, scaled according to local social and individual experience. As pointed out by Kövecses, "[m] uch of our understanding of the world comes through the frames we have associated with our categories. The frames constitute a huge and complex system of knowledge about the world. This large network of frames reflects the knowledge that we make use of in using language (e.g., figuring our meaning) and thinking about and acting in the world. The frames that we use are not only cognitive in nature but also cultural constructs; hence the term cultural models for the same idea" 34 . Frames are defined as "... structured mental representations of an area of human experience (i.e. objects or events). As such, they amount to representations of prototypes (...). Frame-like structures have received a variety of names in the literature, including model, idealized cognitive model, domain, script, scene, experiential gestalt, folk theory, and several others" 35 .

Cultural model is defined by D'Andrade as "a cognitive schema that is intersubjectively shared by a social group" ${ }^{36}$. According to Holland and Quinn, cultural models are "presupposed, taken-for-granted models of the world that are widely shared (although not necessarily to the exclusion of other, alternative models) by the members of a society and that play an enormous role in their understanding of that world and their behavior in it" ${ }^{37}$. For Burenhult and Levinson "cultural models are culturally formed cognitive schemas which determine how human reality is constructed and interpreted in thought and action" 38 . 
Kövecses points out that "cultural models exist for both concrete and abstract concepts, as well as for those that fall somewhere between the two extreme ends on the scale of abstraction" 35 . Because cultural models are a cognitive tool used by people to process and organize information, make decisions and guide behavior ${ }^{39}$ we have cultural models of practically everything from the cultural model of human body, of healthy eating and of creativity, to that of language.

Geeraerts ${ }^{40}$ and Polzenhagen and Dirven ${ }^{41}$ thus study two central competing cognitive cultural models in Western thinking about language, the rationalist model and the romantic model. The two models exhibit specific metaphoric and metonymic conceptualizations of language, e.g. language as a tool in the rationalist, and language as an identity marker in the romantic model.

We even seem to have a cultural meta-model, i.e. a cultural model of cultural models, i.e. a model about what cultural models are/should be. Part of this meta-model is the expectation that there should be just one cultural model per phenomenon. Specifically, we tend to expect that a cultural model fits one cultural community, and conversely, that one culture accommodates a single model about a single phenomenon. The truth is that in reality we may simultaneously entertain several parallel models, opposing each other, competing with each other, or complementing each other. They can also be embedded into more general models.

This also applies to the folk model of language. So, in addition to a general folk or cultural model of language, we also have expert models. Within the former, we also have more specific folk models about particular languages. It appears that we are dealing most of the time with more or less complex (dia)systems of cultural models. Cultural models also tend to be of dynamic nature, i.e. they appear, evolve over time, get modified, and may also disappear.

Not surprisingly, the folk model of language also consists of several sub-models. One such sub-model, mainly based on metonymies is discussed in Radden ${ }^{42}$. He examines various the ways in which notions of articulation are metonymically used in different languages to stand for 'speaking' and 'language'. These unidirectional metonymic shifts and their metaphoric elaborations reflect a naive view of language, which may be seen as revealing a "folk model of language". In this simplified model, our understanding of speaking and language is reduced to articulation and a small set of speech organs. The throat and voice are associated with meaningful speech. The tongue is commonly seen as the generator of a word's sounds and meaning and, as the most salient articulator, tends to be associated with the notion of 'language,' (tongue, German Zunge, in addition to Sprache, Croatian jezik, Hungarian nyelv). The mouth as the second most important articulator may also contribute to a word's meaning. The teeth and the lips may, as the final articulators in the production of speech, distort a word's meaning (durch die Zähne sprechen, close-lipped). Related to this are names for na- tionalities and languages in certain languages which have to do with the use of language, and which may be considered to be social stereotypes about language. The Slavic autonym Slověninz is usually considered a derivation from slovo "word," and ultimately from sloviti "speak". It originally denoted "people who speak/hear (the same language)," i.e. people who understand each other. This contrasts to the Slavic word denoting "foreign people" - němci, meaning "mumbling, murmuring people" (from Slavic němъ - "mumbling, mute"). This word, in various forms is used in many Slavic languages in the sense of "German", e.g., Polish Niemiec, Ukrainian Himeub, Czech Nermec, Slovak Nemec, Russian and Bulgarian Hемеu, Croatian Nijemac, Slovene Nemec, Serbian Heмau, etc. Similarly, German is referred to as német in Hungarian, which is clearly related to néma "mute". On the other hand, the Hungarian for Hungarian is magyar. This root is found in the verb magyarazni "explain".

As mentioned above, people often have folk models of particular languages. There is, for example, a folk-theory-like stereotype about the language of Eskimos or Inuit based on the belief that there were dozens of specific words for various types of snow and ice. This was made popular in the course of the simplification of the so-called Sapir-Whorf Hypothesis. People apparently have certain stereotypic beliefs about a given language: many people feel that Italian is melodic and rhythmic, that spoken Spanish is very fast, that French is elegant and strongly associate nasalized vowels with it, while German is felt to be harsh. A stereotypic conceptualization of German, of its phoneme inventory (in particular stressing sequences such as $/ \int \mathrm{t} /$ or $/ \mathrm{gr} /$ and its vowel alteration by umlaut), its rhythm and syntactic structure underlies the famous Adenoid Hynkel Speech in the movie The Great Dictator by Charles Chaplin ${ }^{\mathrm{a}}$.

\section{Walking the Central and Eastern European Gastronomic Landscape}

In this part we analyse a range of examples of restaurant names displaying metonymic shifts, often along complex metonymization paths, moving from simpler, sublexical elements towards word-size elements and ending with some utterance-size elements as the locus or the starting point of these metonymic operations. The material on which this part is based mainly consists of Croatian and Hungarian restaurant names. Their current (or past) locations are also specified with the help of the Google Plus codes, based on latitude and longitude, but displayed as a series of number and letters, all in all 20 alphanumeric characters followed by the name of the settlement (village, town, or city). Locations that are even as close as $10 \mathrm{~m}$ are assigned different codes, which enables a very precise identification of a place. To give an example, my institution (Faculty of Humanities and Social Sciences in Osijek) is located at HM5J+G9 Osijek.

\footnotetext{
a https://www.youtube.com/watch?v=isLNLpxpndA
} 
There are virtually no limits on what can function as a restaurant name. However, all names are a sort of message to potential guests. Names help create the identity of the locality, the staff, the product and the service. The name of a restaurant can simply be or consist of the name of the owner or the chef, or it could be related to a dish or an ingredient of a dish (e.g. Meatology or Babka in Budapest, the latter is a Middle-Eastern restaurant named after a type of Ashkenazi Jewish bread cake), a piece of the equipment or furniture (for example Sofra in Zagreb, a Bosnian restaurant named after the traditional Oriental low dining table or tray), or it could also be the name of the place where the restaurant is located (for example, Dubravkin put 'Dubravka's path' in Zagreb, located in the street with that name, or Börze 'stock exchange' in Budapest, located just across the former building of the Budapest stock exchange), or some other place name.

Sometimes restaurants are named after far-away locations that suggest the cuisine of a different part of the same country or of a foreign country. Chinese restaurants are thus often called Peking, Shanghai or Guangzhou (the Chinese counterpart of Canton). It is apparent that these places metonymically activate the conceptual domain of a foreign country (PART FOR WHOLE) and also of its culture, part of which is of course cuisine (WHOLE FOR PART). However, it is also possible for the name of a restaurant or the bar to metonymically evoke the locality in which or close to which it is situated because it mentions something associated with that locality. This was the case with the Zagreb restaurant called $K$ veselom mrtvacu ('to the merry corpse/dead man'), which was located in the Mirogojska street, the street leading to Mirogoj, the central cemetery in Zagreb. The name also metonymically suggested the suitability of the establishment for post-funeral consolation feast for the relatives of the deceased. In a number of places in Hungary (e.g. Tapolca, Kaposméró) inns located near the cemetery are called Lesz Vigasz ('there will be comfort/consolation'), clearly also punning on Las Vegas.

In the central part of this article, intended as a pilot study checking the applicability of metonymy as one of the central phenomena in cognitive linguistics to the study of linguistic landscape, we now analyse some restaurant names that are not based only on personal or geographical names, but contain a linguistic element that metonymically evokes a language, and then a country, its culture and finally its cuisine. However, we begin with some limiting cases. In some of these there is a personal name, but its function is to activate the concept of a foreign country and/language. In two examples of the so-called gastronomic fusion there is another element in the name, too, which suggests the fusion, i.e. mixing of various cooking styles in innovative ways. Not surprisingly in both cases, we also have blending at the lexical/constructional level. The first example is Fidel Gastro, the name that immediately suggests the Cuban revolutionary leader, Fidel Castro. There are restaurants of that name in Zagreb (RX54+8J Zagreb) as well as in Budapest (G335+F2 Budapest). While the Budapest establishment indeed seems to be based on Cuban gastronomy, and especially on cocktails, the former is a restaurant that has a general Latino cuisine, but explicitly insist on fusion, combining elements of different culinary traditions from different countries, regions and culture. In this case the first name, Fidel, metonymically activates Fidel Castro (GENERIC FOR SPECIFIC), from which we get to the concept of revolution (PERSON FOR A CONCEPT ASSOCIATED WITH THAT PERSON). This concept combines with gastro in order to narrow down the domain in which this "revolution" takes place, producing fusion cuisine. There is of course also a weaker metonymic path to the region, and from there to the Latin American cuisine.

The other example is the name of a gourmet bakery in Budapest, Jacques Liszt (F3V2+X2 Budapest). The first element is obviously a French name, the second appears to be the name of the famous Hungarian composer Ferenc (Franz) Liszt. Liszt was a person exhibiting lots of contrasts and blending thereof. He may have been Hungarian nationalist, but he was also a cosmopolitan, spending much of his life in France, Switzerland, Germany and Italy and Austria. He was deeply religious (Roman Catholic), and also wanted to join the church as a monk, but he was also a free mason. In sum, he was a good example of cultural fusion. As a musician, he was also innovative, even revolutionary. Both of these characteristics enter in the qualification of the bakery under discussion. There is another level of fusion, or confusion, here, actually a piece of fine punning that rests on homonymy. The French name is pronounced very similar to the Hungarian noun $z s a ́ k$, meaning 'sack' (the vowel is actually longer), while the name of the composer is homonymous with the Hungarian noun liszt 'flour' (Ferenc Liszt's father, Adam List, was a Danube Swabian German, and the family name was later changed to Liszt). However, although all this blending may suggest that this bakery would be a place of the fusion of the French with the Hungarian, it is in reality a fusion of Italian and Hungarian bakery styles.

The last example of a restaurant containing a personal name to be briefly analysed here is Chez Chabane, a Bosnian-style fast foot outlet in Osijek, now permanently closed. The first element is obviously the French preposition, while the second is the name of the long-time owner and the person in charge of the grill, Šaban, spelt (and possibly pronounced) the French way. This name suggesting the stereotype of the elegance of the French language, the French language, and the haute cuisine, stands in sharp contrast with the reality, and is a good example of situational self-irony, which becomes obvious when one studies the following picture showing how shabby the exterior of the place looked like.

Sometimes it is impossible to attribute the linguistic element to a particular language. Another fast food outlet in Osijek, Abrakebabra, shared its name with a whole chain of similar outlets in Ireland, but there are also places with the same name in the Czech Republic and Poland. The name itself is an intercalar blend, where the name of the dish, kebab, is inserted into the middle of the other word with which it is blended, the incantation word abra- 


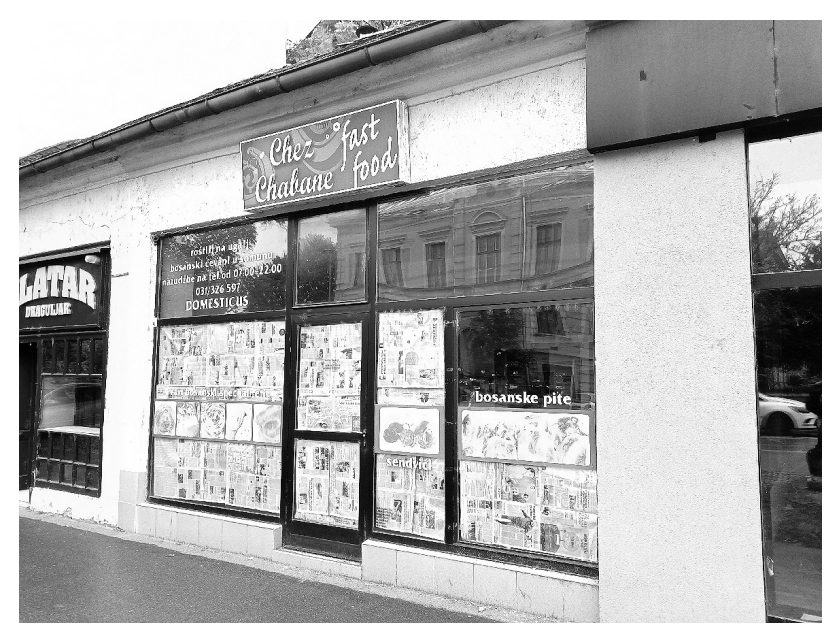

Fig. 1. The front of Chez Chabane in Osijek, photographed by the author.

cadabra. While one element correctly suggests a sort of Oriental fast food menu (DISH FOR CUISINE TYPE), the other, of unknown origin (though associated with a number of folk etymologies), suggest magic and transformation. This same idea is preserved in the current name of the Osijek establishment, Hokus okus, where the Croatian word okus 'taste' is blended with another well-known incantation formula hokus pokus/hocus pocus.

Our next example with an element that can be attributed to a foreign language, and which has nothing to do with names or dishes, is Kíván-csí, a Chinese fast food bar in Hódmezővásárhely, a town in the Southeast of Hungary. The photograph was taken in the September of 2012, and the bar has meanwhile been closed.

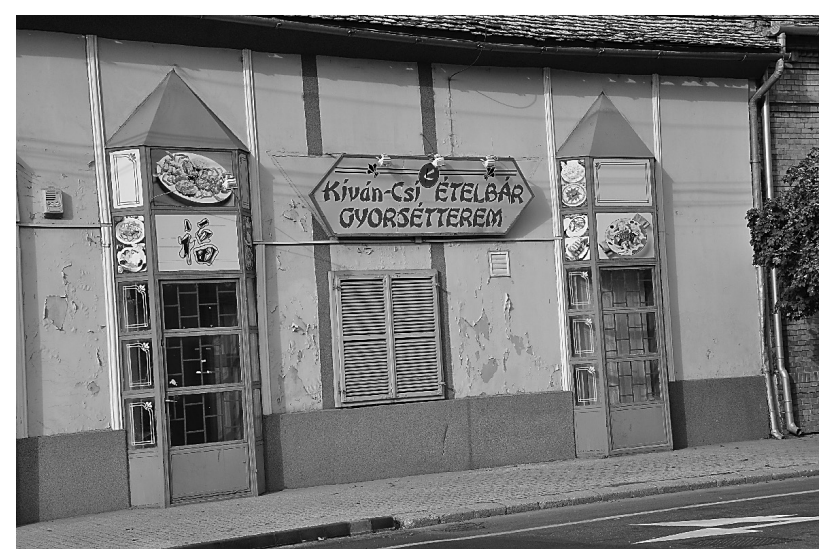

Fig. 2. The front of the fast-food restaurant Kivan-csí in Hódmezövásárhely photographed by the author.

The very first thing we notice are the stylized letters used in the name board, resembling Chinese characters. Graphemes/graphemic elements and particular diacritics characteristic of a particular language can by themselves metonymically evoke that language.
As an example of how this can be achieved by making use of just a single diacritic, consider the logo (actually a logomark) of the Instituto Cervantes, with text and figures in white against the red background.

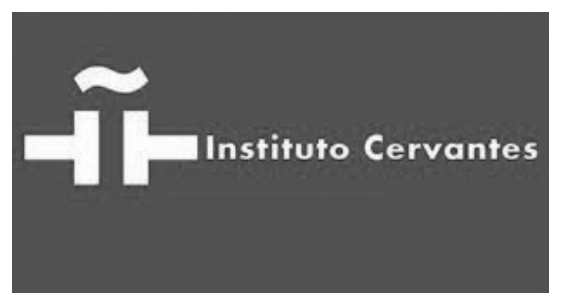

Fig. 3. The logo of the Cervantes Institute (Instituto Cervantes).

The pictorial part of this logo is very simple and consists of two pairs of lines, such that the two horizontal stripes touch two vertical sticks that run parallel to each other, topped by a wavy line in the middle. This wavy line is nothing else but the diacritic called tilde, which appears in Spanish over the letter $n$, as in $\tilde{n}$, called eñe / enye/ in Spanish. This is of course no coincidence - the logo was created by Enric Satué. He said that a sign "as Spanish as eñe was the appropriate one to integrate that image".

So, this is not just a diacritic integrated into the image, the tilde is a metonym for the Spanish language, and the language is further used metonymically to convey the concept of Hispanidad 'Spanishness', the Spanish-speaking world and its culture. The tilde as a metonymy for the Spanish language is also employed in the logo of the Spanish-language news channel of CNN, with a single tilde extending over the two letters $\mathrm{N}$.

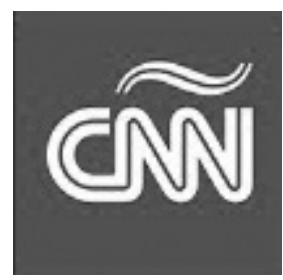

Fig. 4. The logo of the Spanish version of CNN.

Metonymically activating the link from a script type to language is a popular route that designers use when creating the visual identity of restaurants, in particular of restaurants in "diaspora". We can illustrate this with a Georgian restaurant called Chama Mama in New York (though there is also one in London). Its logo is reminiscent of the Georgian script (closest to the Mkhedruli alphabet, rather than Nushkuri or Asomtavruli, the two older Georgian alphabets).

\footnotetext{
b Span. Un signo tan español como la eñe, era el indicado para integrar esa imagen. The background information can be found at: https://arzucomunicacion.lunaazul.org/2017/04/27/15-logos-historia-diseno-grafico/.
} 


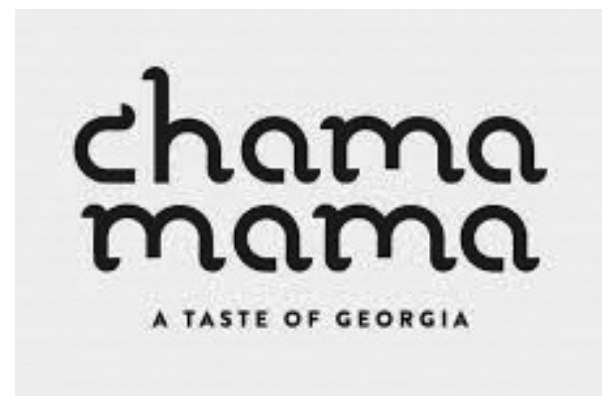

Fig. 5. The logo of the Georgian restaurant Chama Mama in New York

However, the letters used here do not correspond to any letters that would have been used to spell Chama Mama, the second word is spelled in Georgian as $\partial s \partial s$. Incidentally, this word does not mean 'mother', as might have been expected but, surprisingly, 'father' ('mother' being coэюs in Georgian, prounced as /deda/). An even closer match to the Mkhedruli script can be found in the logotypes of various Georgian restaurants in Russia owned by the Gosti Group. The two restaurants in Sochi are Gostidze and Gostidze Riviera. Their logotypes very effectively blend Mkhedruli and the Russian Cyrillic script, as can be seen in the following figures:
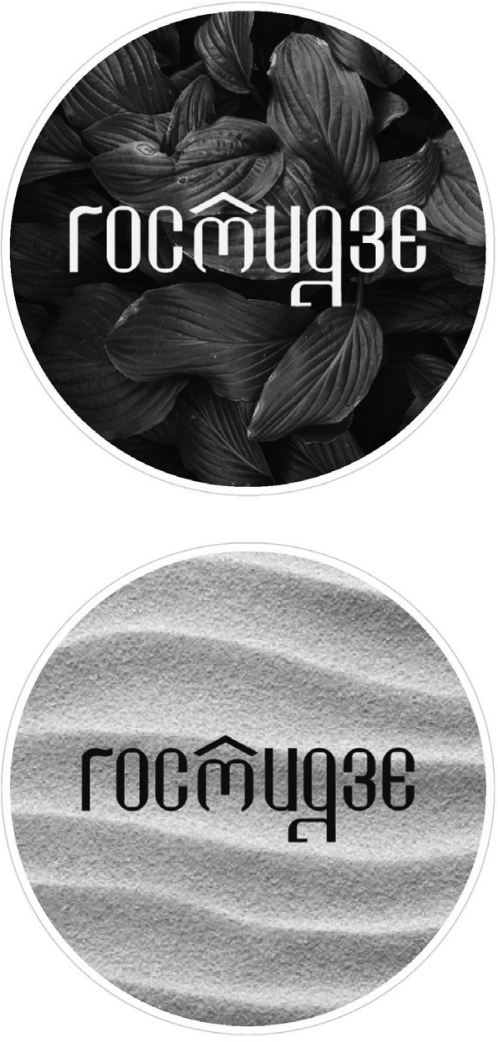

Figs. 6 and 7. The logos of the two Gostidze restaurants.

\footnotetext{
${ }^{\mathrm{c}}$ https://www.facebook.com/chamamamanyc/.
}

We will return to the textual part of the logotypes somewhat later.

The same effect can be achieved for other scripts as well, such as Japanese, German (Gothic letters), Thai, etc. In the logo of the Sawasdee, the Thai restaurant in Budapest, we detect Latin letters stylized as Thai letters, as well as genuine Thai letters (Semmelweis Street 2, Budapest, F3V5+M9 Budapest):

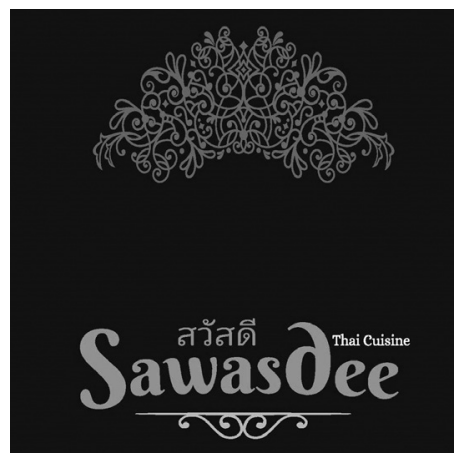

Fig. 8. The logo of the restaurant Sawasdee in Budapest ${ }^{d}$.

Returning to the Chinese fast food bar in Hódmezővásárhely, it turns out that the link to the Chinese language is doubly motivated by metonymy. It is not just the stylized letters, but also by breaking the Hungarian word kiváncsi 'curious, exhibiting curiousity'. A hyphen is inserted between the first two and the third syllable, separating csi (misspelled here as csí) from kiván. This is phonologically very close to the Chinese word $\operatorname{ch} i$ or $\operatorname{ch} \bar{\imath}$

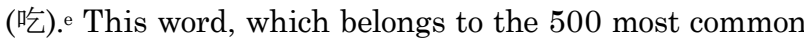
Chinese words, is polysemous, meaning 'to eat' "to suffer', 'to take something, e.g. a chess piece, from an opponent in a game', or 'to annihilate'. If we concentrate on the first meaning, we realize how funny the name of the restaurant is. The first part of the hyphenated name, kiván, assumes its original meaning which has become opaque in kívánc$s i$ 'curious' (etymologically related to kivan, the derived adjective originally meaning something like 'wishing to know'). Assuming that the second component, csi is an allusion to $c h i$ or $c h \bar{l}$, meaning 'eat', we get as a result of the wordplay, something like "wishing to eat'. We now may also realized that the diacritic on the last vowel letter (marking that the vowel is long) could be purposeful, it is of course wrong in the case of the word kiváncsi, but it makes this splinter closer to the Chinese word that is most likely targeted, as it indeed contains a long vowel. Last but not least, we should realize that all this wordplay just goes to make the eatery appear more exotic and its guests more curious, which is also suggested by the Hungarian word kíváncsi.

\footnotetext{
d https://www.facebook.com/chamamamanyc/.

e Note that the Hungarian spelling, and the pronunciation of the splinter, i.e. ( $\left.\mathrm{t} \int \mathrm{i}\right)$, cannot be anything but just an approximation of similar-sounding Chinese words. In addition to $c h i / c h \bar{\imath}$, this might have also been $q i / k i$ or ch’i (气), meaning 'vapout/air/breath'.
} 
In other words, we have two metonymies converging on the same target, i.e. the Chinese language. One is activated by the letters resembling Chinese characters, the other by the splinter of the Hungarian word separated from the rest, which resembles a genuine, fairly frequent Chinese word. The language then metonymically activates the concept of the culture associated with that language, and finally we narrow this domain to the cuisine of the culture in question.

Now we return to the Georgian restaurant name Gostidze, to which we can also add the name of another restaurant, also found outside Georgia, viz. Veselidze. There are two such restaurants in Almaty (Kazakhstan), one in Saint Petersburg (Russia). In both of these names we can recognize the ending - $d z e$, one of the (stereo)typical endings on Georgian family names (e.g. Shevardnadze, or Gamkrelidze). As many as seven out of the ten most frequent Georgian family names ends in - $d z e$, followed by -shvili (e.g. Dzhugashvili) with the other three. The former means 'son', the latter 'child'. The first part of the name Veselidze is apparently based on the Russian adjective весельй, 'cheerful, merry', i.e. it seems as if it were a hybrid Russian-Georgian suffixation. However, the name may be also a blend of the Russian word and the former name of a street in Old Tbilisi, Leselidze (after Konstantin Leselidze, a Soviet military commander of Georgian origin), now called Kote Abkhazi, which is a popular place for tourists, with churches, a synagogue, museums and many restaurants. The Russian word in question may be the adjective, but it could also be the reflexive verb derived from the adjective: the Russian reflexive suffix, - $c$, being phonologically similar to the Georgian family name suffix -dze.

In the name $L a$ štruk, a Zagreb restaurant (Skalinska street 5, RX7G+XP Zagreb, Croatia), we can recognize the name of one of the taditional dish popular in the northwest part of Croatia that is made from dough filled with various ingredients (typically cottage cheese) and which can be cooked or baked, štrukle or štrukli. The name is normally used in the plural, singular being štrukla.

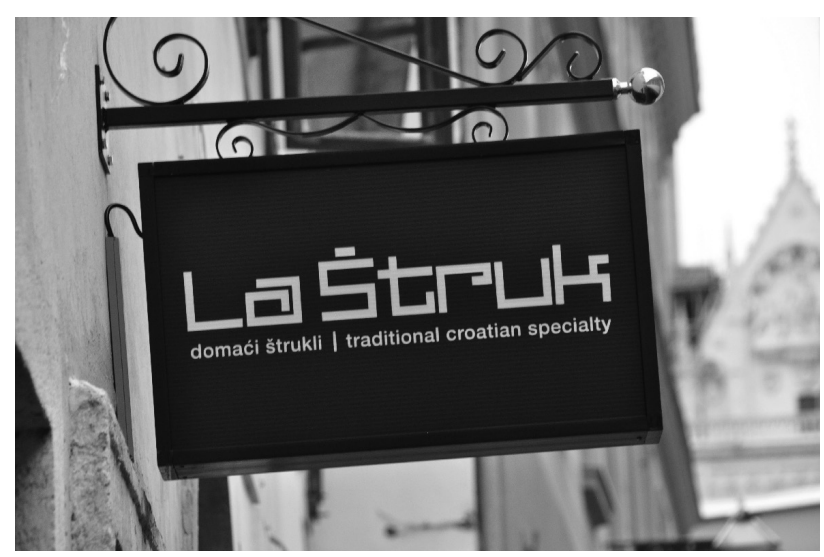

Fig. 9. The name board of La štruk in Zagreb, photographed by the author.
In creating the name of the restaurant, the name of the dish was first broken into its two syllables, and their order was then reversed, i.e. we have a case of permutation. This is a little known method of producing alternative forms of slangy words as in the Sarajevo Bosnian greeting expression vozdra (from $z d r a-v o$ ) or in the Croatian malić, as in the name of the toyshop chain Turbo limać, from mali 'small' + diminutive suffix - ić, presumably meaning 'small kid'.

Returning to La štruk, we see that the two syllables were not just permuted, but made into what appears to be two independent words. The first of these obviously resembles a Romance language definite article. It is easy to associate it in the present context with Italian or French. Specifically it is identical with the definite article for singular feminine nouns that begin with a consonant. This is a fairly clear case of the metonymic activation of a language in the first step, from which a metonymic broadening of the frame can then take place to the culture as its target. Finally, we have a metonymic narrowing to just part of that frame, viz. to the cuisine. It might be the Italian language, and the Italian culture and cuisine because one of the widespread stereotypes about the Italian cuisine is that it is above all pizza, spaghetti, lasagne and similar dishes whose main ingredient is dough in one form or another. Another stereotype, or a substereotype, or most likely even a fact, is that Italian pasta is the best in the world. Finally, another substeretype is that the best recipes come from grandmothers, so they are traditional and home-made. So, by associating štrukle, and the restaurant under discussion, with the Italian cuisine suggests that it offers quality home-made, traditional Croatian dishes based on dough. However, it is also possible that the associated language is French, if one pronounces the second component with a uvular thrill, /R/. In that case, the line metonymies would again be similar, as described above, but with no attending irony.

Another example of restaurants/eateries that exploit the metonymic link with the Italian cuisine via the Italian language activated by the use of the same definite article are Hungarian establishments called La'Koma Grill (Pesti Road 5-7, Budapest, F6MH+76 Budapest), just La'Koma (Kevermes, Jókai Street 1, C58J+GR Kevermes) or (Szorgalmatos, Mező Street 27X9PF+VF Szorgalmatos), or La Coma Pizza (Dunakeszi, Fóti Road 101, J5C6+3X Dunakeszi). La, is followed here by Coma or Koma, is the first syllable of the Hungarian word lako$m a$, meaning 'feast'. This Hungarian word is simply split into two parts, with a modified or original spelling of the other two syllables. Replacing $k$ with $c$ makes the whole look even more Italian.

It is not only individual morphemes and words that can start the metonymic inference from a linguistic element of a given language to the whole language, and then further to culture and cuisine. In the case of the Zagreb restaurant Jazz.ba Chevap (Varšavska Street 8, Zagreb, RX6F+Q3 Zagreb, now permanently closed), the first el- 
ement has nothing to do with music, but is just a funny anglicised version of the first part of a very frequent utterance that functions as a sort of shibboleth for people coming from Bosnia, followed by ba after a dot - des'ba! (a syncopated utterance corresponding to Gdje si, ba!). This is not a genuine question, but rather a conversational gambit, close to just Hey! Ba is a variant of bolan, also as bona, all functioning as a particle, as in Šta ima, ba? 'What's up?', Daj, ba! 'Come on', Huala, ba! 'Thanks, bro!'

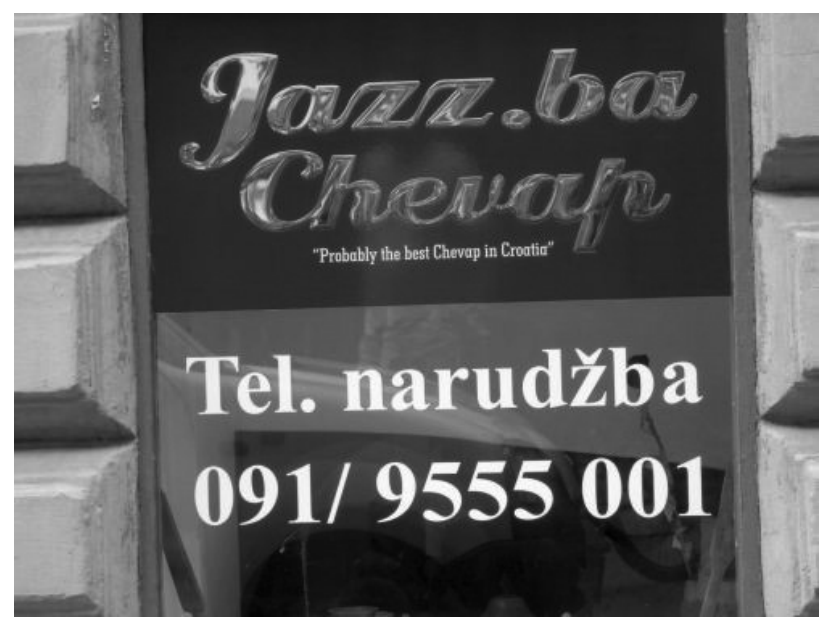

Fig. 10. The window of Jazz.ba Chevap in Zagreb

Note also that $b a$ is separated from jazz by a dot. As it happens.$b a$ is the ccTLD (country code top-level domain) for Bosnia and Herzegovina in web addresses, i.e. URLs. In its own right it would have been strong enough to mildly activate the conceptual domain of Bosnia and Herzegovina, but it is strengthened when joined by jazz, which also lengthens the metonymic path (from language to country to culture to cuisine). It could also be assumed that there is also a certain degree of self-irony involved here. The English word jazz may at first suggest some posh club for intellectuals listening to this particular type of music, activating certain elitist expectations, consonant with the slogan 'foreign is better.' However, it turns out that this is a fast food establishment for ordinary, average people, if not for lower and lower middle classes, completely free of the allures suggested by the use of a world language.

Chevap, the playful anglicized from of cevap (usually in the plural or in the longer form cevapčići, a grilled dish of minced meat found traditionally in the countries of southeast Europe, but considered a national dish of Bosnia and Herzegovina) further helps identify the type of cuisine in question by recourse to a stereotype. The same strategy based on a stereotype of a national/regional type of cuisine can be seen at work in names of restaurants containing the names of cooking utensils, or names of dishes. In the former category we have several Zagreb restaurants with wok that evoke South-East Asian cuisine, most likely Chinese or Thai, like Wok by Matija, Wok One Restaurant, or Wok and Walk/Wok' $n$ Walk, Wok Me, as well the redupli- cated name Wok-Wok in Osijek. Similarly, in Budapest we find Happy Wok, Taipei Wok, Wok Express, and Buddha Mini Thai Wok Bar, among others. In the other category we have names of restaurants containing names of dishes, such as Laguna Sushi, Planet Sushi, etc. Note also La štruk, discussed above as an example of a more domestic dish. Similarly, we find Gulyás Étterem (Goulash restaurant), and Gettó Gulyás (ghetto goulash), the latter is in Dohany Street, part of the tradional Jewish quarter in downtown Budapest. Restaurant names can mix the two in various ways, as in the case of Budapest restaurants called Wasabi Running Sushi \& Wok, Wok \& Tandoori (Indian, Tibetan, Nepali, Thai and Indonesian style food), or WokZilla Sushi and Wok Bar.

\section{Conclusion}

Linguistic landscape is a relatively novel concept in contemporary linguistics, somewhere at the junction of sociolinguistics, sociology, social psychology, geography and media studies, but in this article, using examples of creative restaurant names, I show that there is also a very important cognitive linguistic aspect to it. Specifically, I point out the role of metonymy in the creation of these names. In this pilot study, my intention was not to study all the restaurant names in a given area, but to focus only on restaurant names that contain one or more elements from a language different from the rest of the restaurant names, concentrating on the gastrolinguistic landscape of Central and Eastern Europe, primarily Croatia and Hungary. The foreign languages involved were English, Italian, and French, but also Chinese, and Georgian, etc.

It has been demonstrated that in addition to some more general cultural models of language, speakers also have a multitude of specific folk models of particular languages, mostly based on stereotypes, which in turn are also metonymic. Linguistic elements that trigger these series of metonymies range from diacritics and script type/alphabet to lexical items and even whole utterances. These activate a series of metonymic inferencing steps most of the time resulting in complex cumulative metonymies such that one is superimposed on the other, the target of one simultaneously functioning as the source for the next one, and so forth.

These complex metonymies can also occasionally run at least in part in parallel, resulting in an interaction of metonymies that can be characterized as metaleptic ${ }^{22}$.

\section{Acknowledgments}

The author acknowledges the support by the Spanish Ministry of Science and Innovation (MICINN), the Spanish State Research Agency (AEI), and the European Regional Development Fund (FEDER) of the European Union project Non-denotational interpretive and descriptive dimensions in meaning construction: integrating linguistic, cross-linguistic, and experimental data (PID2020- 
118349GB-I00) and PGC2018-101214-B-I00 (Researching conceptual metonymy in selected areas of grammar, dis- course and sign language with the aid of the University of Córdoba Metonymy Database) (METGRADISL\&BASE).

\section{R E F E R E N C E S}

1. SEBBA M, Writing Systems Research 2/1 (2010) 73. doi:10.1093/ wsr/wsp006. - 2. LANDRY R, BOURHIS RY, Journal of Language and Social Psychology 16/1 (1997) 23. doi: 10.1177/0261927X970161002. — 3. BACKHAUS P, Linguistic landscapes: a comparative study of urban multilingualism in Tokyo (Multilingual Matters, Clevendon, 2007). doi:10.21832/9781853599484. — 4. VAN MENSEL L, VANDENBROUCKE M, BLACKWOOD R, Linguistic landscapes. In: GARCÍA O, FLORES N, SPOTTI M (Eds): The Oxford handbook of language and society (Oxford University Press, New York, 2017). - 5. HEYD T, Language in Society 43/5 (2014) 489. doi:10.1017/S0047404514000530. - 6. PAPEN U, Journal of Sociolinguistics 16/1 (2012) 56. doi: 10.1111/j.1467-9841.2011.00518.x. - 7. LEEMAN J, MODAN G, Journal of Sociolinguistics 13/3 (2009) 332. doi:10.1111/j.1467-9841.2009.00409.x. - 8. CARR JRC, Signs of our times: Language contact and attitudes in the linguistic landscape of Southeast Los Angeles. PhD dissertation (University of California, Los Angeles, 2017). - 9. AL-NAIMAT G, Brand names in the linguistic landscape of Aqaba, Jordan. PhD dissertation (University of Liverpool, Liverpool, 2015). - 10. GRADEČAKERDELJIĆ T, ZLOMISLIĆ J, Hum 9 (2014) 11. - 11. PILLER I, Ann Rev Appl Ling 23 (2003) 170. doi: 10.1017/S0267190503000254. - 12. BAUMGARDNER RJ, World Englishes 25/2 (2006) 251. doi:10.1111/j.0083-2919.2006.00463.x. - 13. KELLY-HOLMES H, Advertising as multilingual communication (Palgrave Macmillan, Basingstoke, UK, 2005). - 14. BENCZES R, BARCELONA A, RUIZ DE MENDOZA IBÁÑEZ F, Defining metonymy in cognitive linguistics: Towards a consensus view (John Benjamins, Amsterdam, 2011). doi: 10.1075/ hcp. 28. - 15. BARCELONA A, Reviewing the properties and prototype structure of metonymy. In: BENCZES R, BARCELONA A, RUIZ DE MENDOZA IBÁÑEZ F (Eds): Defining metonymy in cognitive linguistics: Towards a consensus view (John Benjamins, Amsterdam, 2011). doi:10.1075/hcp.28.02bar. - 16. LAKOFF G, JOHNSON M, Metaphors we live by. (University of Chicago, Chicago, 1980). - 17. KÖVECSES Z, RADDEN G, Cognitive Linguistics, 9/1 (1998) 37. doi: 10.1515/ cogl.1998.9.1.37. - 18. PANTHER, K-U, The role of conceptual metonymy in meaning construction. In: RUIZ DE MENDOZA FJ, PEŃA CERVEL S (Eds): Cognitive linguistics: Internal dynamics and interdisciplinary interaction (Mouton de Gruyter, Berlin, 2005). doi:10.1515/9783110 197716.4.353. - 19. RUIZ DE MENDOZA FJ, OTAL CAMPO JL, Metonymy, grammar, and communication (Editorial Comares, Albolote, 2002). - 20. RUIZ DE MENDOZA IBÁÑEZ F, DÍEZ VELASCO OI, Metonymic motivation in anaphoric reference. In: RADDEN G, PANTHER K-U (Eds): Studies in linguistic motivation (Mouton de Gruyter, Berlin, 2004). - 21. BRDAR M, Metonymy and word-formation: Their interactions and complementation (Cambridge Scholars Publishing, Newcastle upon Tyne, 2017). — 22. BRDAR-SZABÓ R, BRDAR M, Metonymic indeterminacy and metalepsis: Getting two (or more) targets for the price of one vehicle. In: SOARES DA SILVA A (Ed): Figurative language - Intersubjectivity and usage (John Benjamins, Amsterdam,
2021). doi: 10.1075/ftl.11.06brd. — 23. RUIZ DE MENDOZA FJ, The role of mappings and domains in understanding metonymy. In: Barcelona A (Ed): Metonymy and metaphor at the crossroads (Mouton de Gruyter, Berlin, 2000). doi: 10.1515/9783110894677.109. - 24. RUIZ DE MENDOZA FJ, DÍEZ VELASCO OI, Patterns of conceptual interaction. In: DIRVEN R, PÖRINGS R (Eds): Metaphor and metonymy in comparison and contrast (Mouton de Gruyter, Berlin, 2002). doi:10.1515/978311021 9197.4.489. — 25. RUIZ DE MENDOZA FJ, MAIRAL USÓN R, Highlevel metaphor and metonymy in meaning construction. In: RADDEN G, KÖPCKE K-M, BERG T, SIEMUND P (Eds): Aspects of meaning construction (John Benjamins, Amsterdam, 2007). doi:10.1075/z.136.05rui. — 26. RUIZ DE MENDOZA FJ, PÉREZ HERNÁNDEZ L, Language and Communication, 21/4 (2001) 321. doi:10.1016/S0271-5309(01)000088. - 27. BARCELONAA, Introduction. The cognitive theory of metaphor and metonymy. In: BARCELONA A (Ed): Metaphor and metonymy at the crossroads. A cognitive perspective (Mouton de Gruyter, Berlin, 2000). doi:10.1515/9783110894677.1 - 28. Barcelona A, On the plausibility of claiming a metonymic motivation for conceptual metaphor. In: BARCELONA A (Ed): Metaphor and metonymy at the crossroads. A cognitive perspective (Mouton de Gruyter, Berlin, 2000). doi:10.1515/9783110894677.31. - 29. ULLMANN S, Semantics: An introduction to the science of meaning (Blackwell, Oxford, 1962). - 30. TAYLOR JR, Linguistic categorization: Prototypes in linguistic theory (Clarendon Press, Oxford, 1989). - 31. RUIZ DE MENDOZA FJ, PEÑA CERVEL S, Jezikoslovlje, 3/1-2 (2002) 131. — 32. KÖVECSES Z, Metaphor: A practical introduction (Oxford University Press, Oxford, 2002). doi:10.1017/S0047404503254051. - 33. HERRERO-RUIZ J, Metaphor and Symbol, 35 (2020) 266. doi:10.1080/10926488.2020.1820304. - 34. KÖVECSES Z, Language, mind and culture. A practical introduction (Oxford Univesity Press, Oxford, 2006). - 35. KÖVECSES Z., Metaphor in culture. Universality and variation (Cambridge University Press, Cambridge, 2005). doi:10.1017/CBO9780511614408. - 36. D'ANDRADE $\mathrm{R}$, A folk model of the mind. In: D. HOLLAND D, QUINN N (Eds): Cultural models in language and thought (Cambridge University Press, Cambridge, 1987). - 37. QUINN N, HOLLAND D, Culture and cognition. In: D. HOLLAND D, QUINN N (Eds): Cultural models in language and thought (Cambridge University Press, Cambridge, 1987). - 38. BURENHULT N, LEVINSON SC, Language Sciences, 30 (2008) 135. doi:10.1016/j.langsci.2006.12.028. - 39. D'ANDRADE RG, The development of cognitive anthropology (Cambridge University Press, Cambridge, 1995). doi:10.1017/cbo9781139166645. — 40. GEERAERTS D, Cultural models of linguistic standardization. In: DIRVEN R, PÜTZ M, FRANK $\mathrm{R}$ (Eds): Cognitive models in language and thought (Mouton de Gruyter, Berlin, 2003). doi:10.1515/9783110892901.25. - 41. POLZENHAGEN F, DIRVEN R, Rationalist or romantic model in globalisation? In: KRISTIANSEN G, DIRVEN R (Eds): Cognitive sociolinguistics (Mouton de Gruyter, Berlin, 2008). doi:10.1515/9783110199154.3.237. — 42 RADDEN G, metaphorik.de 1 (2001) 55.

\section{Brdar}

Faculty of Humanities and Social Sciences, University of Osijek, L. Jägera 9, 31000 Osijek

e-mail:mbrdar@ffos.hr 


\section{ŠETNJA GASTROLINGVISTIČKIM KRAJOBRAZOM S METONIMIJOM KAO VODIČEM}

\section{S A Ž E T A K}

U članku se razmatra uloga metonimije u gastrolingvističkome krajobrazu, posebice njezina uloga u stvaranju poruke gostima u imenu restorana. Lingvistički krajobraz relativna je novina u suvremenoj lingvistici te je metodologija njegova proučavanja još uvijek u previranju, dok teme i pristupi postaju sve raznovrsniji. Nakana je članka pokazati da su kognitivnolingvistički aspekti proučavanja jezičnoga krajobraza veoma važni. U članku se konkretno pokazuje uloga metonimije u kreativnim imenima restorana koja sadržavaju jedan ili više elemenata nekoga jezika različitoga od jezika ostatka imena, s naglaskom na restorane u središnjoj i istočnoj Europi, u prvome redu u Hrvatskoj i Mađarskoj. Pokazuje se da pored nekih općenitih kulturnih modela jezika govornici imaju i mnoštvo specifičnih pučkih modela pojedinih jezika, većinom utemeljenih na stereotipima (koji su također metonimijske naravi). Ti pučki modeli aktiviraju niz koraka metonimijskoga zaključivanja, što u većini slučajeva rezultira kompleksnim kumulativnim metonimijama, pri čemu je jedna metonimija temelj za sljedeću metonimiju na višoj razini, tj. cilj jedne metonimije ujedno je i izvor druge metonimije itd. 
